"Strategic management or sustainable decisions in business: A case of greening the transport companies"

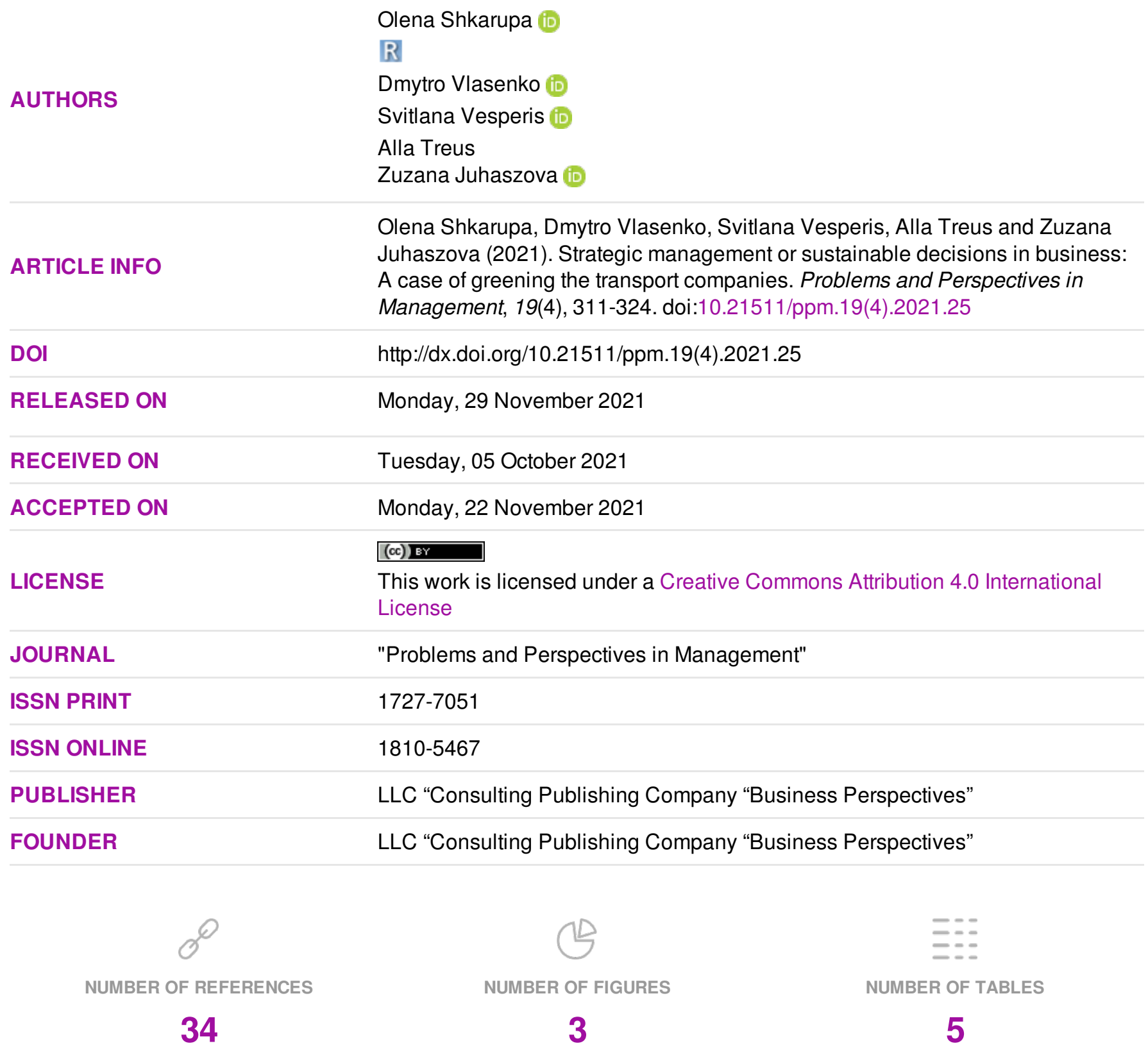

(C) The author(s) 2021. This publication is an open access article. 


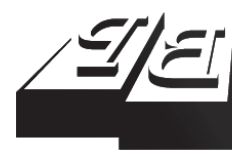

\section{BUSINESS PERSPECTIVES}

(O)

LLC "CPC "Business Perspectives" Hryhorii Skovoroda lane, 10 Sumy, 40022, Ukraine www.businessperspectives.org

Received on: $5^{\text {th }}$ of October, 2021 Accepted on: 22 $2^{\text {nd }}$ of November, 2021 Published on: 29 $9^{\text {th }}$ of November, 202

(C) Olena Shkarupa, Dmytro Vlasenko, Svitlana Vesperis, Alla Treus, Zuzana Juhaszova, 2021

Olena Shkarupa, Doctor of Economics, Professor, Department of Economics, Entrepreneurship and Business Administration, Sumy State University, Ukraine. (Corresponding author)

Dmytro Vlasenko, Ph.D., Associate Professor, Sumy State University, Ukraine.

Svitlana Vesperis, Ph.D., Associate Professor, Sumy State University, Ukraine.

Alla Treus, Ph.D. student, Sumy State University, Ukraine.

Zuzana Juhaszova, PhD., Associate Professor, University of Economics in Bratislava, Slovak Republic.

Olena Shkarupa (Ukraine), Dmytro Vlasenko (Ukraine), Svitlana Vesperis (Ukraine), Alla Treus (Ukraine), Zuzana Juhaszova (Slovakia)

\title{
STRATEGIC MANAGEMENT FOR SUSTAINABLE DECISIONS IN BUSINESS: A CASE OF GREENING THE TRANSPORT COMPANIES
}

\begin{abstract}
Elaboration of steps for the strategic management of environmentally sound business solutions is essential for achieving sustainable development goals in Ukraine. Although strategic directions for decarbonization of the transport sector have already been developed at the national level, effectiveness of sustainable decision-making is closely related to the greening initiative on the local level. The purpose of the paper is to form a framework of greening strategy and sustainable decision-making for transport companies that is based on the necessity to reduce emissions. The research findings are obtained using the systems analysis, SWOT analysis, and cost-benefit method. The paper proves that choosing biogas (methane) as a main transport fuel is a viable and cost-effective initiative and can be used as a financial ground for the company's strategic formation process that involves both tactical and organizational dimensions. The analysis results also showed threats and opportunities for greening based on switching transport companies to biogas and requiring steps of governmental support in developing biogas station networks. According to the green course, this study also reveals the possibility of establishing strategic management due to an authority delegation map between services and top management of a transport company. The study has made it possible to improve strategic management of a transport company by developing an optimal scheme of interaction between stakeholders and departments in strategic leadership for greening.
\end{abstract}

Keywords

JEL Classification

\section{INTRODUCTION}

Ukraine is one of the countries facing climate change challenges, and transport is a primary source of air pollution in Ukrainian cities. Today the most critical problem is the absence of a strategic plan for switching the transport companies to a green course that requires additional costs and specific instruments to develop and implement cost-effective solutions to respond to emissions challenges in the transport sector. Energy consumption and transport impact on the environment in Ukraine do not meet modern requirements (MIU, 2018). Inefficient fuel use in conditions of energy shortages and an increase in the number of cars create prerequisites for increasing carbon dioxide emissions, nitrogen oxide, non-combustible hydrocarbons, lead, benzene, carbon monoxide, particulate matter, etc. Ukraine is one of the six countries of the Eastern Partnership where environmental pollution dynamics are deteriorating year by year. In 2019, the European Union announced the approval of the Green Deal, and Ukraine was one of the first to tell that it would follow these green initiatives. The 
EU Green Deal's main document for reducing emissions in the transport sector is the Sustainable and Smart Mobility Strategy, adopted in 2020 (EC, 2020).

Unlike other sectors of the national economy, transport cannot absorb or capture emissions, so the main tactic is to reduce emissions. Transport companies require significant efforts to develop appropriate modernization strategies and to make a transition to a green course. Despite the need for modernization, transport companies cannot quickly switch to a green method to reduce emissions. This is primarily due to the low level of prompt response to market challenges and the lack of strategic plans for greening at municipal transport enterprises.

Eco-friendly strategic plans and strategies of transport companies' development require high intellectual and organizational costs with unguaranteed results in the future. However, strategic management of entrepreneurial structures is vital and widely used in practice. In developing countries, the level of strategic management is relatively low due to the following reasons: lack of a sufficient number of skilled personnel, weak corporate culture, low predictability of economy, lack of actual material, etc. The implementation of strategic management elements by Ukrainian enterprises is multiplied but not widely used by transport enterprises. Each enterprise is unique and requires an individual approach to manage its sustainable development and define its strategy.

Under the conditions of economic changes and environmental modernization, modern transport companies, which carry out city transportations like any other enterprise that manufactures goods or services, face many problems. The sources of the increased complexity of management are high uncertainty in the market situation, seasonal instability in demand for road transport services, rigidity of competition in the industry, lack of financial resources, etc.

Therefore, there is a need for strategic thinking, which should be embodied in a program of actions that clarifies goals and means of implementation of the chosen path of development. Transport companies' long-term survival and growth depend on their ability to predict market changes in time and appropriately adapt their organizational structure and content of order portfolio for goods and services according to international standards. Thus, the search for approaches to forming sustainable decision-making methods for transport companies is relevant.

\section{LITERATURE REVIEW AND THEORETICAL FRAMEWORK}

\subsection{Highlights of relevant studies}

Sustainable development means the need for a transport to switch to alternative motor fuel types primarily caused by the intense rigidity of environmental requirements for exhaust gases and oil scarcity (Matsenko \& Ovcharenko, 2013; Kurbatova et al., 2020). Koilo (2019) emphasized that the use of renewable energy has increased due to energy efficiency policies and technological leadership in the shipbuilding industry. Today, many countries adopted vital requirements for greening of transport companies. The European
Union is scheduled till 2020 to transform about a quarter $(23 \%)$ of an entire car park for alternative fuels: natural gas $-10 \%$, biogas $-8 \%$, hydrogen (fuel cells) - 5\% (Van Grinsven et al., 2021). Gas is a clean uncontaminated motor fuel and additives, due to which the emission of toxic substances into the environment is reduced by 10 times, and the service life of the engine is extended by 1.5-2.0 times. Natural gas complies with the highest environmental standard - Euro-6. This is especially important to reduce the negative impact of road transport on the environment (MIU, 2018). The transport sector needs drastic reductions based on high estimates, as is shown in the EU White Paper on Transport (Domergue \& Markovic-Chénais, 2012). The EU aims to reduce overall greenhouse gas emissions (GHG) by $80 \%-95 \%$ by 2050 (Figure 1). According to findings, energy-saving technol- 


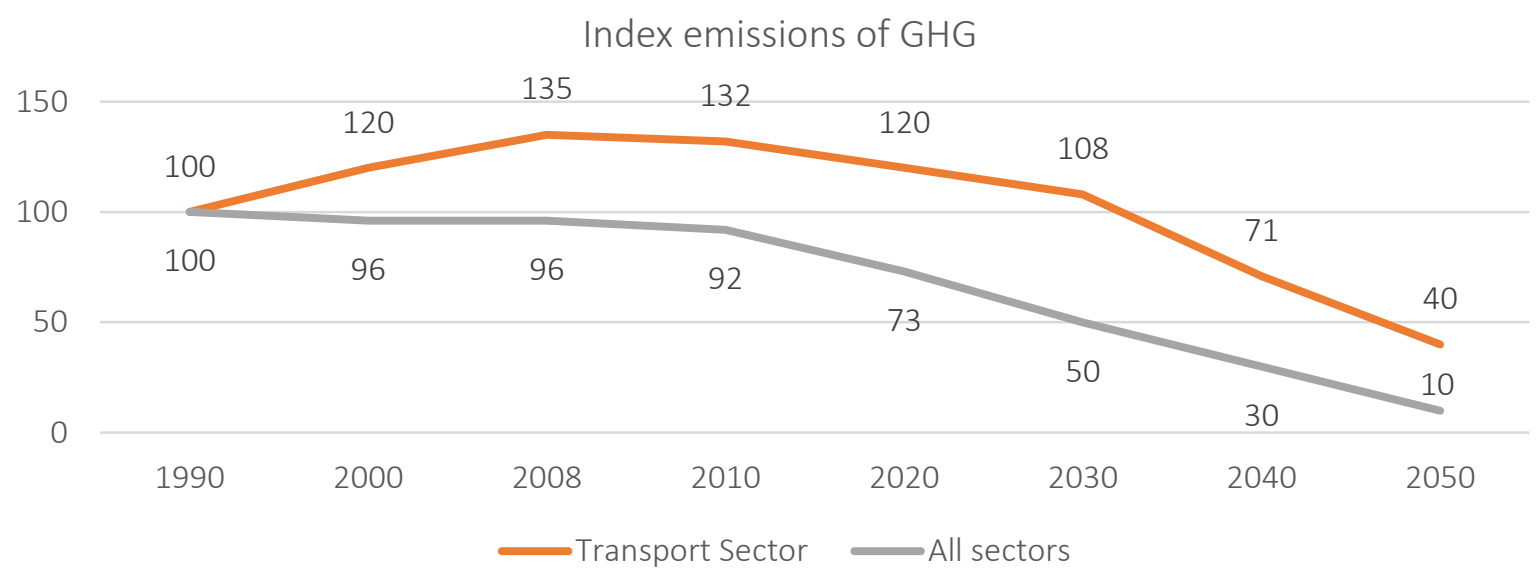

Figure 1. Targets for emissions of GHG for transport and all sectors

ogies are a topical issue today in the transport business (Apbin, 2015). According to Garkushina (2008) and NISS (2013), constructors and developers are actively interested in this issue, as in the future it can bring significant benefits to the society, as well as to the state.

Domergue and Markovic-Chénais (2012) set up the idea that decision-makers should apply the precautionary principle to all external costs, adopt a long-term vision, and act today. Another factor, which could have an impact on decision-making and describe companies' behavior is the stage of corporate life cycle and corporate management (Durana et al., 2021). The Slovak public transport operator replaced two buses with new energy-efficient vehicles, which contributed to meet current emission and safety standards and become more sustainable (GEFF, 2021).

To gain the targets, the EU supports companies and individuals in their efforts to succeed in sustainable decision-making. Thus, a British resident who is about to buy an electric car will pay an annual tax of less than a quarter of the cost of the vehicle (but does not exceed $£ 5,000$, or USD 7,800 ). The tax benefit will be up to $20 \%$ of its value, albeit with a ceiling of $£ 8,000$ (USD 12,500) when it comes to commercial electric cars. It is tax incentives that most governments in Europe connect to stimulate the transition to electricity: such practices exist in 15 of the 27 Member States of the European Union (Darguzhit, 2011; Sotnyk et al., 2020a; Bhandari, 2019). Chatti (2020) considered reducing the negative impact on environmental sustainability from truck transport through the proper use of information and communication technologies.

Both private and legal persons in Estonia can receive a grant to purchase an electric vehicle in the amount of $50 \%$ of its value (but not more than 18,000 euros per vehicle or 200,000 euros - several). The money for the purchase of a car is additional 1 thousand euros for the purchase and installation of a "home" charger. The Portuguese government pays a subsidy of 5,000 euros to every citizen who buys a new electric car. There is also a stimulus for the secondary market of electric vehicles: when purchasing a used electric vehicle, a citizen receives a grant of 1,500 euros from the state (Sotnyk et al., 2020b; Sotnyk, 2012). Any electric cars in the country are exempt from the registration fee. In Denmark, in addition to the annual income tax benefits in Europe, owners of electric vehicles weighing up to $2,000 \mathrm{~kg}$ are exempt from registration. In addition, electric cars receive free parking in the capital city of Copenhagen.

The USA program provides for a government grant to electric car buyers. It is $25 \%$ of the cost of the machine. It encourages the purchase of a home charger - tax benefits of $50 \%$ of the charging price (up to USD 2,000) are provided. Obviously, for these reasons, the United States today is the country in which the widest range of electric vehicles is represented: from first-generation electric Toyota RAV4 to Chinese BYD (Ablaev, 2007). In Japan, because of the state incentive system, the Mitsubishi i-MiEV is reduced from the initial 4 
million yen to 2.8 million yen. The "discount" includes abolishing taxes, including a one-time purchase and an annual transportation fee.

At the beginning of 2019, the Clean Vehicles Directive was adopted in Europe to develop a market for vehicles with zero or low emissions and encourage their use in public procurement. The directive sets minimum objectives for "clean" light-duty vehicles, trucks, and buses for 2025 and 2030. According to these rules, by 2030, up to $65 \%$ of new buses should be "clean". It is assumed that half of this value can be achieved using methane in transport (EC, 2020). The European and American experience shows that it is necessary to maintain a sustainable consumption of natural resources that are used to produce biofuels, which in turn will entail minimizing environmental pollution

In Ukraine, the development of electric transport has low dynamics, as well as the transition to another kind of fuel, is a problem. There are no financial state investments in the field of electric vehicles and autonomous electric transport - electric buses, electric trucks, etc. The government adopted legislative regulation and the abolition of certain taxes (in particular, value-added tax and import duties were abolished). Thanks to that, the development of the electric vehicle market started in 2015 (MIU, 2018). According to statistics, in Ukraine the car park on methane does not exceed 30,000 units. Unlike electric vehicles for methane-powered vehicles, there are no import and use incentives.

However, most importantly, Ukraine has excellent potential for the rapid development of this area with little investment. First, Ukraine has the second-largest natural gas reserves in Europe, making this market less dependent on the global environment. Second, the Ukrainian gas transportation system (38 thousand kilometers of pipelines) has a very high level of distribution in the regions, making it possible to create the necessary infrastructure of filling stations in any settlement or on a large highway.

On the other side, there are many problems concerning greening strategy because transport companies in the current market conditions do not deliberate to develop a strategy for switching to alternative energy sources. Existing methodological approaches of strategic processes of transport companies do not fully consider peculiarities of strategic plans and development strategies that require greater intellectual and organizational costs in the case of unsure results in the future.

\subsection{Stages of strategic management for sustainability}

The main ideas for the transition of the business sector to sustainable development were laid down in the 1990s. The concept of sustainable development needs to be incorporated into the business policies if it follows sustainable development principles (Deloitte \& Touche, 1992). Thus, it requires a new orientation and extensive refinements to practices and procedures, but it does not mean that new management methods need to be invented. The scientific literature provides a wide range of different frameworks regarding the transport sector towards sustainability, but in this study, it will be limited to the important issue under analysis - strategic management. Dimić et al. (2016) describe strategic management models. The study widely contributes to understanding the problems of strategic management and the establishment of sustainable development. There are a lot of various models and systems for managing multicriteria decisions. Thus, Teles and de Sousa (2014) assess energy efficiency initiatives, value-based thinking methodology, and decision support methods that provide a suitable tool for integrated sustainability. They define that there are three stages of strategic management: problem structuring, problem analysis, and problem-solving. There are six steps in the problem structuring phase: identifying and engaging stakeholders, defining the problem, defining sustainability issues, defining decision criteria, defining alternatives, and identifying benefits.

Summing up the basic ideas, one can determine that mechanism of managing an organization's strategic development is a set of principles, methods, functions, and instruments of managerial influence on the functioning of a company, which will help managers to ensure sustainable development. One of the priorities for sustainable business decision-making is to ensure that transport companies meet the economic, social, and environmental needs of society 
while minimizing the impact on the economy, society, and the environment. For Ukrainian companies, it means to fulfill international obligations within the EU Sustainable and Smart Mobility Strategy framework with the active coordination of different stakeholders and local governments. EU Sustainable and Smart Mobility Strategy (EC, 2020) proposes enhancing taxed carbon emissions and providing better incentives for users. It includes the continuous application of the "polluter pays" principle: those who use it should pay for pollution from transport, not all citizens and taxpayers. It means, for example, that owners of cars with internal combustion engines must pay more for air pollution and greenhouse gas emissions than owners of electric vehicles, and pedestrians and cyclists do not have to pay at all. It is proposed to introduce a sufficient payment for the use of infrastructure, including roads. In doing so, people should be informed about the most sustainable and environmentally friendly modes of transport they could use (EC, 2020).

Summarizing the practical experience of Ukrainian companies in current conditions, the strategic decisions can be classified according to such criteria: basic strategy; the level of decision-making (or the level of management hierarchy); the degree of "aggressiveness" of the organization's behavior in the competition; the relative strength of the sectoral position of the economic entity (Peresadko et al., 2014). Methodological approaches of strategic processes of transport companies are not fully considering peculiarities of strategic plans and development strategies that require greater intellectual and organizational costs in the case of unsure results in the future. This implies a greater depth of analysis for developing objectives for greening decisions considering eco-friendly modernization trends (Nadanyiova, 2018).

The paper aims to form a framework for greening strategy and sustainable decision-making of transport companies that is based on the necessity to reduce emissions and gain sustainable development.

\section{METHODS}

This paper uses SWOT analysis. A business strategy is developed that focuses on using strengths and opportunities, compensating for deficiencies, and reducing the influence of risk factors while choosing biogas as a company's transport fuel. Evaluation of the strategy is carried out by comparing the results of the work done with the previously set goals. The criterion for assessing the success of individual projects of an organization can be used as the basis for strategic decisions. The indicators of the economic efficiency of the costs of developing a greening strategy depend on the very process of converting vehicles to alternative energy sources.

In the case of implementing the greening strategy at a transport company, cost-effectiveness indicators for the cost of re-equipment of vehicles depend on the structure of the stock and its technical and operational indicators, first of all, the average annual mileage of cars. The payback period for the re-equipment of transport will be calculated by the brands of trucks since different models have different fuel consumption and average annual mileage. To obtain an economic effect, it is first necessary to switch to biogas of transport units with higher fuel consumption (25 liters per $100 \mathrm{~km}$ and more) and an annual mileage of more than 30 thousand $\mathrm{km}$.

The cost of biogas for the operation of one truck for one year, considering the coefficient of increase in consumption, is calculated by:

$$
T_{g}=\frac{N_{f} \cdot M \cdot I_{g}}{100} \cdot p
$$

where $N_{f}$ - is a one-time rate of fuel consumption per $100 \mathrm{~km} ; M$ - is the average annual mileage of the truck; $I_{g}$ - is the coefficient of increase in income; $p$ - is the price for 1 liter of biogas.

The difference in costs (saving on fuel cost) by the cost of fuel for operating one truck for one year is calculated by:

$$
S_{t}=T_{f}-T_{g},
$$

where $T_{f}$ - cost of diesel fuel consumption for the operation of one truck for one year.

To analyze the payback period $(T)$, the paper used the cost of technical installation of gas equipment for one truck $\left(\mathrm{C}_{\text {inst }}\right)$; saving on fuel cost for 1 month $\left(S_{t}\right)$; the number of cars $(n)$ : 


$$
T=\frac{\left(C_{\text {inst }} \cdot n\right)}{S_{t} / 12} .
$$

A systematic approach to the management of a transport company is also a widespread and recognized method, basic principles and patterns of which are widely used in strategic management. Proceeding from the foundations of a systematic approach, the study draws a connection between individual greening projects, as well as their impact on the overall greening strategy.

\section{RESULTS AND DISCUSSION}

Forming a green strategy and switching vehicles to alternative fuels improves the environmental status of the region and saves the financial resources of state and commercial organizations. One of the alternative motor fuels is biogas (methane-purified) produced by households and agricultural producers. The introduction of gas engines powered by biogas will allow providing a significant contribution to the problem of resource conservation by reducing the consumption of scarce oil motor fuels; mitigating urban air pollution with particularly harmful car exhaust components, primarily carcinogenic components; ensuring a significant economic impact by reducing fuel costs and reducing environmental damage (Table 1).

The practicality of alternative fuels on transport except for fuel and energy considerations should be assessed from the economic feasibility of their conduct and use in the economic system. In the process of developing an acceptable green strategy for its development, the transport company should consider a comprehensive assessment of its current position on the market and opportunities for further activity.

The economic efficiency of switching vehicles to biogas (methane) was assessed using the next factors that determine efficiency:

1) there is practically no difference in fuel consumption per $100 \mathrm{~km}$;

2) the lowest unit cost.

Table 2. Fuel consumption factors for $100 \mathrm{~km}$

Source: Authors' elaboration

\begin{tabular}{|c|c|c|}
\hline Type of fuel & $\begin{array}{c}\text { Fuel cost } \\
\text { of UAH/1 liter }\left(1 \mathrm{~m}^{3}\right)\end{array}$ & $\begin{array}{l}\text { Cost factor } \\
\text { for } 100 \mathrm{~km}\end{array}$ \\
\hline petroleum & 30.12 & 1 \\
\hline biogas/methane & 23.84 & 1.05 \\
\hline propane-butane & 17.48 & 1.2 \\
\hline diesel fuel & 28.38 & 1.1 \\
\hline
\end{tabular}

The results received are based on calculating the costs of the payback period of motor vehicle re-equipment of the company. The data for calculating fuel consumption are presented in Table 3. When developing a greening strategy, it is necessary to calculate the total economic efficiency of transferring trucks to work on gas fuel. To

Table 1. Key benefits, costs, and risks of stakeholders in implementing a green strategy

Source: Authors' elaboration.

\begin{tabular}{|c|c|c|}
\hline Stakeholders & Key benefits & Costs and risks \\
\hline Consumers & $\begin{array}{l}\text { - Reducing fuel costs } \\
\text { - Reduction in overall inflation } \\
\text { - Reduction of environmental damage } \\
\text { - Improving engine wear resistance, } \\
\text { fuel economy }\end{array}$ & $\begin{array}{l}\text { - Costs for transferring vehicles to gas fuel } \\
\text { - Risk of additional mileage of motor vehicles due to the poor } \\
\text { - Risk of rising prices for alternative fuels (through the abolition } \\
\text { of state regulation) } \\
\text { - Increasing costs of maintenance and repair of motor vehicles }\end{array}$ \\
\hline National economy & $\begin{array}{l}\text { - Sustainability of subsoil resources } \\
\text { - } \text { Reducing inflation } \\
\text { increase in property taxes and } \\
\text { companies } \\
\text { - } \text { Reduction of budget expenditures } \\
\text { on fuel }\end{array}$ & $\begin{array}{l}\text { - Costs of implementing regulatory measures } \\
\text { - Reduction of taxes on the sale of petroleum products }\end{array}$ \\
\hline Owners of gas stations & $\begin{array}{l}\text { - Relatively high investment } \\
\text { - High profitability and fast payback }\end{array}$ & $\begin{array}{l}\text { The risk of slow growth in demand for alternative fuels } \\
\text { - Development rates of natural gas and electricity vehicles }\end{array}$ \\
\hline $\begin{array}{l}\text { Owners of the national } \\
\text { gas company }\end{array}$ & $\begin{array}{l}\text { - New markets for products } \\
\text { - Reducing costs of fuel }\end{array}$ & $\begin{array}{l}\text { - Risk of slow demand for fuel and lubricants } \\
\text { - Risk of a low load of power stations }\end{array}$ \\
\hline
\end{tabular}


Table 3. Cost-benefit calculations

Source: Authors' calculations based on SSS of Ukraine (n.d.).

\begin{tabular}{|c|c|c|c|c|}
\hline Car type (unit) & $\begin{array}{c}\text { Savings per day, } \\
\text { UAH }\end{array}$ & $\begin{array}{c}\text { Cost of switching to a gas } \\
\text { of a total number of cars, } \\
\text { UAH }\end{array}$ & $\begin{array}{l}\text { Savings per } \\
\text { month, UAH }\end{array}$ & $\begin{array}{c}\text { Payback period, } \\
\text { months }\end{array}$ \\
\hline PAZ-672 (7) & $3,023.0$ & $300,706.0$ & $90,690.0$ & 3.3 \\
\hline PAZ-3205 (6) & $2,438.4$ & $283,146.0$ & $73,152.0$ & 3.9 \\
\hline PAZ-3206 (8) & $3,352.8$ & $340,576.0$ & $100,584.0$ & 3.4 \\
\hline LAZ-695“N" (15) & $8,001.0$ & $721,905.0$ & $240,030.0$ & 3 \\
\hline LAZ-695“NG” (17) & $9,499.6$ & $836,570.0$ & $284,988.0$ & 2.9 \\
\hline LAZ-699“P” (7) & $3,822.7$ & $302,050.0$ & $114,681.0$ & 2.6 \\
\hline GAZ-3221 (15) & $3,581.4$ & $557,595.0$ & $107,442.0$ & 5.2 \\
\hline
\end{tabular}

do this, the paper considers the costs of further maintenance and current repairs of the installed equipment.

According to the calculations, the savings from the re-equipment of trucks at $\phi$ company " $\mathrm{N}$ " are for each type of truck from UAH 3.02 thousand up to 9.5 thousand UAH. As one can see from the results of the calculations, the economic efficiency in the operation of gas-powered cars (75 pcs.) will allow on average to save more than 1011,57 thousand UAH for fuel per month, and after 2.6-5.2 months the re-equipment of the transport will be paid off.

The simplest and most popular method of articulating the direction of an organization's development is the SWOT analysis. The methodology of SWOT analysis involves first identifying strengths and weaknesses, threats and opportunities, and then establishing the links between them, which can be used to form the strategy of a company. According to the calculations, a SWOT analysis was carried out, confirming the economic efficiency of transferring trucks to biogas, the data of which are presented in Table 4.

Based on the analysis of information on the external and internal environment of a company and the results of a SWOT analysis, it highlights what it should focus on:

1) Ensuring the use of a cheaper type of fuel $\rightarrow$ Reducing the cost of transportation.

2) Improving engine performance $\rightarrow$ Reduced engine repair costs.

3) The ability to refuel vehicles directly in the fleet using local gas networks $\rightarrow$ Savings to eliminate runs to refueling and back.

Table 4. SWOT analysis of a transport company implementing a greening strategy by switching to biogas

\begin{tabular}{|c|c|}
\hline Strengths & Weaknesses \\
\hline $\begin{array}{l}\text { - Environmentally and economically attractive and safe: reducing } \\
\text { the harmfulness of emissions when switching vehicles to natural } \\
\text { gas. Lack of sulfur and lead in exhaust gases } \\
\text { - Gas fuel prolongs the engine performance } \\
\text { - Powerful technical base } \\
\text { - Qualified management and staff } \\
\text { - Ability to quickly adapt to changing demand and timely update } \\
\text { its range (offer new routes) } \\
\text { - High social image on a local level } \\
\end{array}$ & $\begin{array}{l}\text { - Irrational structure of the rolling stock } \\
\text { - High transportation costs } \\
\text { - Low quality of services provided } \\
\text { - Lack of funds for development } \\
\text { - High cost of transferring vehicles to gas equipment } \\
\text { - Refueling with gas is slower than gasoline, diesel } \\
\text { - If the operating rules are not followed, medical hazards may } \\
\text { arise }\end{array}$ \\
\hline Opportunities & Threats \\
\hline $\begin{array}{l}\text { - The possibility of diversification of activities } \\
\text { - Increase in demand for transportation } \\
\text { - Local government support programs } \\
\text { - Creation of cost-effective, safe, and environmentallyoriented } \\
\text { technologies for the provision of motor transport services } \\
\text { - The possibility of building the biogas filling stations directly } \\
\text { in urban areas and public buildings, including in underground } \\
\text { garages }\end{array}$ & $\begin{array}{l}\text { - Reduced demand for transportation } \\
\text { - High competition } \\
\text { - Lack of regulation } \\
\text { - Tax increases } \\
\text { - Rise in prices for fuel and energy and other resources } \\
\text { - Biogas filling station network hinders the massive conversion } \\
\text { of vehicles to biogas } \\
\text { - Lack of a clear legislative basis for converting vehicles to biogas } \\
\text { and a law on the use of alternative motor fuels }\end{array}$ \\
\hline
\end{tabular}


4) Reduction of air pollution due to the difference in specific emissions of engines running on gasoline $\rightarrow$ Reduction of economic damage from urban air pollution.

5) Ability to utilize household biogas/methane and associated gas production $\rightarrow$ Reducing energy imports, increasing the economic potential of the national economy.

An essential component of strategic management is to demonstrate to the potential national and foreign investors that investing in the development of transport based on alternative fuel sources is profitable and reliable. It requires the regulation of green aspects of the legislative framework and the formation of additional rules. In conditions of instability, intensification of the crisis in the economy, traditional sources of financing energy-saving projects are mainly inaccessible. Sotnyk et al. (2020b) set up the idea that analysis of the innovative environment of Ukraine indicates the lack of state funding and the lack of own funds of enterprises. This environment should be filled with external investment from banking and other financial and credit institutions. In this sense, the economic and credit sector has the maximum potential with comprehensive state support of both potential investors (in terms of refinancing) and potential borrowers. The massive arrival of, for example, banks in this process can significantly accelerate it. In the case of lending for innovation becoming the norm, urgent problems of modernization of the country will be resolved (Apbin, 2015). According to Sotnyk et al. (2020a), Kurbatova et al. (2020), and Zhuravka et al. (2020), tax instruments that stimulate investment processes in the transport sector in Ukraine are investment tax credit; reduction of the VAT refund period, and introduction of a notification procedure for VAT reimbursement for large companies; introduction of a depreciation premium; the possibility of applying high coefficients to depreciation charges for the subjects of special economic zones; regional and local privileges for-profit tax, transport tax, property tax of organizations, land tax; the right to reduce the tax rates for a single tax paid when applying a simplified taxation system. When developing a set of tax incentive measures for investment processes, the importance of having tax benefits not only for medium and large businesses that apply the general tax regime but also for small businesses operating under a special tax regime should be considered.

Peresadko et al. (2014) and Sotnyk et al. (2020b) considered investment forms for innovative and greening initiatives. It was noted that there should be increased and expanded privileges to enhance leasing scales, but imposing restrictions reduces leasing activity. According to Horobchenko and Voronenko (2018), Klymchuk et al. (2020), and Kartanaite et al. (2021), no Ukrainian government financial institutions provide targeted investment for environmental needs. In this regard, a rational step is to simplify the procedure for obtaining an investment tax credit for all types of enterprises with the possibility of obtaining it by small business entities applying special taxation regimes. In conjunction with the special conditions of attribution to expenses of the purchased property, persons applying for a simplified taxation system will receive a strong investment incentive.

The optimal coordination of the processes of implementation, functioning, and development of the strategic management mechanism in transport organizations would be achieved by creating a special unit - a strategic management group (Interfax, 2015). The company's strategic management group should operate on an ongoing professional basis and be directly subordinate to the director. It should be formed from the specialists, representing various structural divisions: the planning and economic department, the marketing service, the production, the dispatch department, the long-term development department, the financial service, etc. It is essential to ensure the overall strategic orientation of individual services of organizational units, involving the process of developing and making strategic decisions is not only top management but also functional linear services, team representatives, and independent consultants. It is foreseen to establish strategic processes in a transport company through a developed map of delegation of authority between services and the top management of a transport company. The distribution of powers between specialists that are part of a strategic management group in the formation and implementation of the company's development strategy is presented in Table 5 . 
Table 5. Flexible delegating map of authority between departments of a company on the forming of a greening strategy

Source: Authors' elaboration.

\begin{tabular}{|c|c|c|c|c|c|c|c|}
\hline \multirow[b]{2}{*}{$\begin{array}{l}\text { Stages of the process of managing } \\
\text { the strategic development for greening }\end{array}$} & \multicolumn{7}{|c|}{ Departments of the company } \\
\hline & 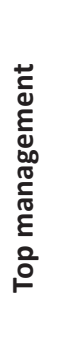 & 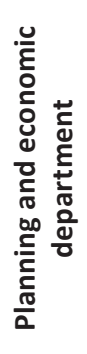 & 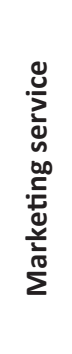 & 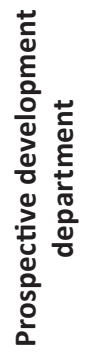 & 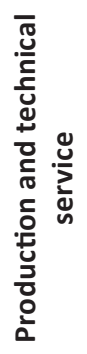 & 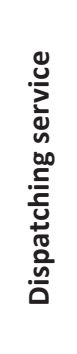 & 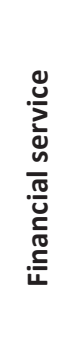 \\
\hline Forming a mission, goals, and clarification of the strategy & $\mathrm{R}$ & $\ln$ & $\ln$ & In & In & In & $\ln$ \\
\hline External environment analysis & $\ln$ & In & $\mathrm{R}$ & In & In & In & $\ln$ \\
\hline Analysis of the internal environment & In & R & In, N & $\ln , \mathrm{N}$ & $\ln , \mathrm{N}$ & $\ln , \mathrm{N}$ & In, N \\
\hline Identification/assessment & $\mathrm{R}$ & $\ln$ & $\ln , \mathrm{N}$ & $\ln , \mathrm{N}$ & In & $\ln$ & $\ln$ \\
\hline Strategy Portfolio Formation & $R$ & $\ln$ & $\ln$ & $\ln$ & In & In & In \\
\hline Development of a strategic plan of greening & $R$ & $\ln , \mathrm{N}$ & $\ln , \mathrm{N}$ & $\ln , \mathrm{N}$ & $\ln , N$ & In & In, N \\
\hline Implementation of a strategy and strategic plan & $\mathrm{R}$ & In & $\ln$ & In & In & $\ln$ & $\ln$ \\
\hline Evaluation of results and feedback & $\mathrm{R}$ & In, N & In, N & In, N & $\ln , \mathrm{N}$ & In & $\ln , \mathrm{N}$ \\
\hline
\end{tabular}

According to the proposed scheme, the activities of the strategic management group during the formation and implementation of a greening strategy would be represented by the following processes: $\mathrm{R}$ - responsibilities for implementing green strategy; $\mathrm{N}$ - providing the source data, information, and methods to greening strategy; In - participation in the implementation of the green strategy.

The main criterion for evaluating the company's development strategy is to achieve the goal of greening. At the same time, particular importance is attached to the financial evaluation of the strategy and strategic development plan. The key role in the organization of the strategic management of the company is played by the process of effective interaction of its services, departments, and officials in the development and implementation of a greening strategy. Since the analysis revealed a tendency towards corporatization of motor transport enterprises, Figure 2 proposes an optimal scheme for the interaction of officials and subsections in the process of managing strategic development.

The scheme allows providing information on the process of implementing a strategic plan and allows timely decisions on adjusting the strategy at

\begin{tabular}{|c|c|c|c|c|c|c|c|}
\hline \multirow[b]{2}{*}{$\begin{array}{l}\text { Stakeholders } \\
\text { (management) }\end{array}$} & \multicolumn{7}{|c|}{ Stages of strategic management for greening } \\
\hline & 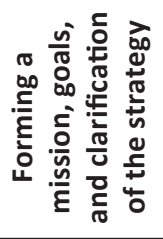 & $\begin{array}{l}\frac{u}{00} \cdot \frac{n}{n} \\
\frac{0}{\pi} \\
\frac{\pi}{\pi} \\
\stackrel{\frac{L}{n}}{\frac{c}{4}}\end{array}$ & 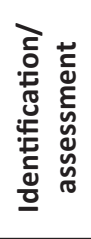 & 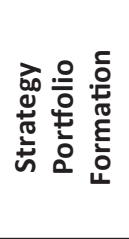 & 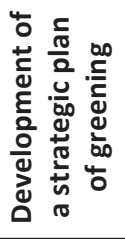 & 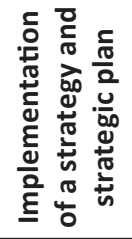 & 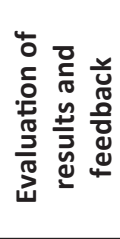 \\
\hline \multicolumn{8}{|l|}{ Shareholders meeting } \\
\hline \multicolumn{8}{|l|}{ Board of directors } \\
\hline \multicolumn{8}{|l|}{ Senior management } \\
\hline \multicolumn{8}{|l|}{$\begin{array}{l}\text { Strategic Management } \\
\text { Group }\end{array}$} \\
\hline Structural subdivisions & & & & & & & \\
\hline
\end{tabular}

Figure 2. Optimal interactions between stakeholders and departments in the process of strategic management for greening 
a specific level. The proposed scheme outlines the role of the board of directors in shaping greening strategy, which is to control that it is carried out in the right direction. Consistent and coordinated implementation of the proposed stages of managing the company's strategic development allows for a logically consistent, accurate, feasible, effective, and unified line of action. Thus, the practical achievement of the company's set strategic goals and development priorities requires the creation of a mechanism for managing its strategic development.

The analysis showed that there is a need to transform strategic processes for the transport company's development model according to the necessity of providing greening initiatives for sustainability (Figure 3). A strategic greening plan acts as a tool for the enterprise progress since it encourages managers to constantly think ahead, leads to clearer coordination of efforts and establishment of performance indicators for con- trol, makes an organization more clearly define its tasks in new market conditions, makes it more prepared for sudden changes (Kraus \& Kauranen, 2009).

The obtained results support earlier findings in the field of implementing greening strategies. Comparing with Garkushina (2008) and Kraus and Kauranen (2009), it was proposed to add a delegating map with a scheme of interactions between stakeholders to the general model of strategic development management. It will allow forming a new model of company development according to the necessity of providing greening initiatives for sustainability. The study revealed that managers of the company with analytical and organizational support will achieve efficient results of greening strategies based on proposed stages of strategic management:

Stage 1. Forming the mission and objectives, forming the greening strategy. Defining prospects of the

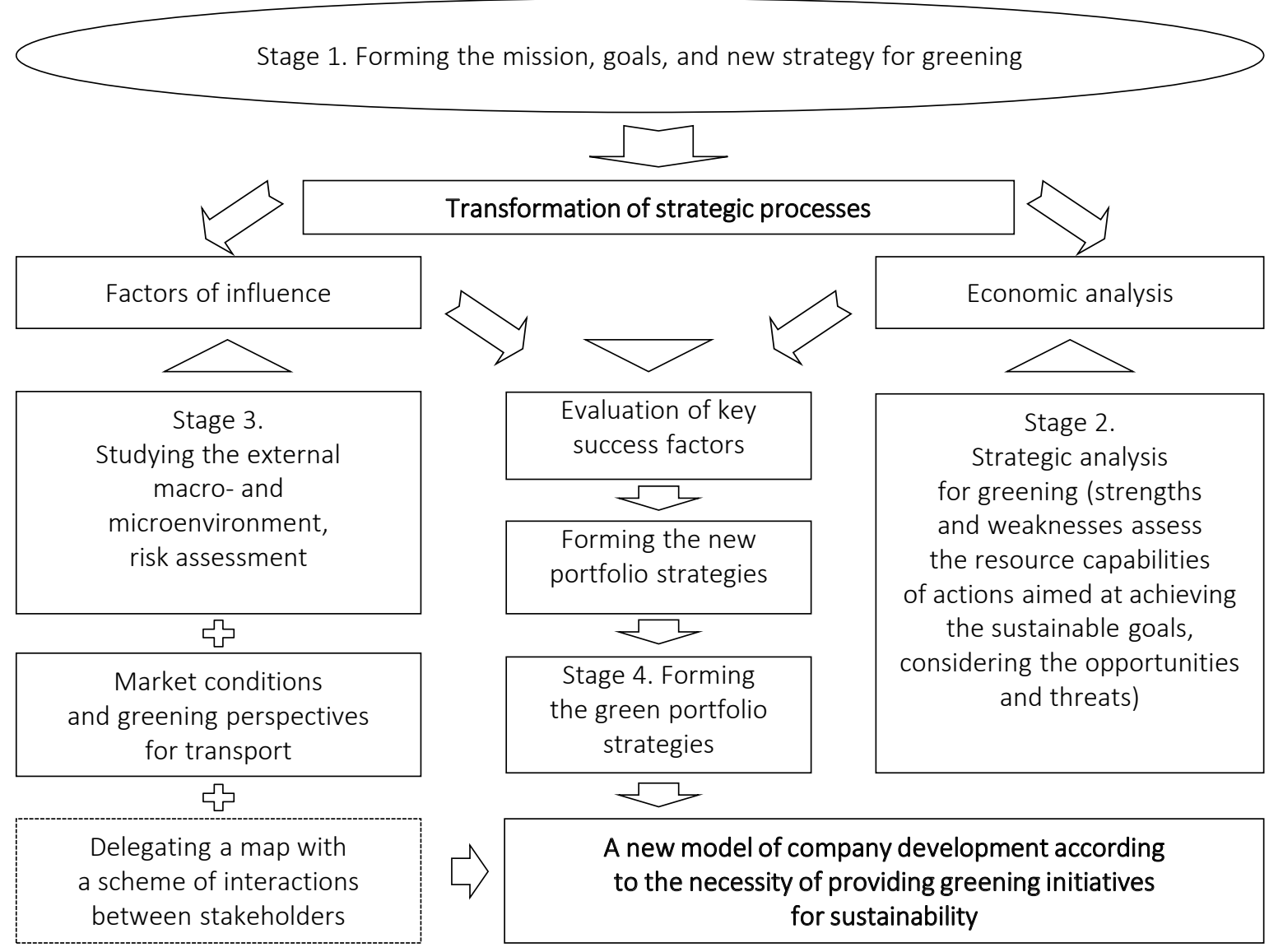

Figure 3. A sustainable model of strategic development management 
green development, its process, and the formulation of tasks help to determine what a company is doing for sustainability: what are its essence, scale, perspectives and growth direction, differences between the competitors.

Stage 2. Strategic analysis for greening. It includes a comprehensive analysis of the internal state of the entrepreneurial structure, because of which its strengths and weaknesses assess the resource capabilities of actions aimed at achieving goals and studying the external macro-environment, risk assessment considering revealed opportunities and threats (through SWOT analysis).

Stage 3. Identification/evaluation of crucial success factors of green initiatives. The estimation of the critical success factors of greening strategy represents the main variables of strategic success. Their identification is one of the main priorities of development strategy and its basis and has industry specifics. For example, social image, resource savings, cooperation with local authorities, the flexibility of service delivery, and more.

Stage 4. Formation of green portfolio strategies of a company. This is the crucial element of the sustainable model of strategic management. A company does not have only one strategic green goal but a few general green purposes. In this regard, it is necessary to form an alternative strategy to achieve each goal. Kraus and Kauranen (2009) note that well-known strategic management instruments, such as benchmarking, GAP analysis, or Balanced Scorecard, which can also be used in SMEs, are often unfamiliar to entrepreneurs, especially if entrepreneurs do not have an educational background in management. However, forming a portfolio of alternative strategies of company development means forming different ways, including the necessity of developing greening perspectives or any other sustainability issues, which will solve sustainable development tasks.

In addition, the efficiency of implementing greening strategies depends on the following:
- improvement of work of the created filling networks, oriented on the satisfaction of transport companies' needs;

- creation of conditions for the switching of transport to biogas and maintenance of gas transport; and

- introduction of a favorable legal and information field on the use of biogas.

Moreover, it is necessary to improve the mechanism for stimulating alternative energy sources and search for ways to transfer transport to alternative fuels (biogas or electricity). It is essential to create favorable conditions and guarantees for carrier organizations participating in government tenders to achieve this aim. The main objective of such changes is the economic security of both individual motor transport enterprises and the region in the face of an acute shortage of resources and the implementation of sustainable development provisions. The object of greening is the motor transport system as a set consisting of hierarchically dependent complex subsystems interconnected using organization, material, and information links to ensure focused activities in the field of meeting the needs of society in transport services. Implementing the mechanism of a gradual transition to alternative sources of fuel is an investment in the future of the Ukrainian economy.

Ukrainian transport companies have to gain a long-term strategy. Then they need to move in line with the system and requirements of the European Union to stimulate the use of alternative fuels. It is necessary to transpose the aforementioned European directives into Ukrainian legislation, which fits well with the Association Agreement with the EU, which requires harmonizing Ukrainian legislation with EU legislation. It is also necessary to make appropriate changes to the Transport Strategy of Ukraine and the Energy Strategy of Ukraine. One of the first steps can be a state program to support the development of biogas filling station networks along transport highways and in settlements. 


\section{CONCLUSION}

This study reveals a framework for the greening strategy of a transport company and the role of strategic management as a critical component of sustainable decision-making for fast adaptation to modern sustainability challenges that transport companies face. To identify the activities for strategic management for sustainable decision-making for business, the most important 4 stages were determined (forming the greening strategy, strategic analysis for greening, identification of crucial success factors of green initiatives, and forming green portfolio strategies of a company).

To transform the strategic process of a company, the economic feasibility of converting transport units to biogas within a transport company was conducted. Calculations concerning economic benefits of choosing biogas as a company's transport fuel showed that a company saves money on biofuel compared to traditional fuel: more than 1011,57 thousand UAH per month during the strategy of greening process implementation. It was demonstrated that in 2.6-5.2 months, the project of switching to more affordable biogas would be paid off. These results formed the basis of the strategic decision-making and were considered via a SWOT analysis. It allowed formulating a logically coordinated scheme of interaction of forces, weaknesses, opportunities, and threats of greening strategy, which includes switching cars to environmentally friendly kinds of fuels based on the scientific method. The SWOT analysis results also showed that one of the first steps of government support must be a state program to develop biogas filling station networks along transport highways and in settlements to realize the greening process in the transport sector.

For sustainable transport business, strategic decisions were formulated that allow applying a delegating map of authority between the company departments on forming a greening strategy. It includes threat mitigation relying on its strength. The study has made it possible to improve strategic management by developing an optimal scheme of interaction between stakeholders and departments in strategic leadership for greening.

To sum up, there are many possibilities for strategic greening initiatives in transport companies. An important issue is still the improvement of governmental mechanisms for stimulating alternative energy sources based on modern international practice such as tax benefits, tax regime, local privileges, etc. Future efforts should establish new rules and conditions for implementing greening strategies to fulfill Ukraine's international obligations within the EU green strategy framework.

\section{AUTHOR CONTRIBUTIONS}

Conceptualization: Olena Shkarupa.

Data curation: Dmytro Vlasenko, Svitlana Vesperis, Alla Treus, Zuzana Juhaszova.

Formal analysis: Dmytro Vlasenko, Svitlana Vesperis.

Funding acquisition: Olena Shkarupa, Zuzana Juhaszova.

Investigation: Dmytro Vlasenko, Alla Treus.

Methodology: Olena Shkarupa, Dmytro Vlasenko, Alla Treus.

Project administration: Olena Shkarupa.

Resources: Olena Shkarupa, Dmytro Vlasenko, Svitlana Vesperis, Alla Treus, Zuzana Juhaszova.

Software: Svitlana Vesperis, Zuzana Juhaszova.

Supervision: Olena Shkarupa.

Validation: Dmytro Vlasenko, Svitlana Vesperis, Alla Treus.

Visualization: Olena Shkarupa, Alla Treus.

Writing - original draft: Dmytro Vlasenko, Alla Treus.

Writing - review \& editing: Olena Shkarupa. 


\section{ACKNOWLEDGMENT}

This study is a part of the Scientific Project "Modeling the Transfer of Eco-Innovations in the EnterpriseRegion-State System: Impact on Ukraine’s Economic Growth and Security” (№ 0119U100364), which is financed by the state budget of Ukraine.

On behalf of Zuzana Juhaszova's contribution, this paper was supported by the Slovak Research and Development Agency under the contract No. APVV-16-0602 Enhancement of the relevance of the accounting data in the SR - from expenses to value.

\section{REFERENCES}

1. Ablaev, A. R. (2007). V SShA polovina benzina - uzhe s dobavkoi bioetanola, a $v$ Rossii rynka biotopliva ne sushchestvuet $v$ printsipe [In the USA, half of gasoline is already supplemented with bioethanol, and in Russia, the biofuel market does not exist at all]. IQHSE. (In Russian). Retrieved from http://opec. $\mathrm{ru} / 1103248 . \mathrm{html}$

2. Apbin, B. (2015). Petlya vremeni: kak biznes izobretaet transport budushchego [The loop of time: how business invents the transport of the future]. Forbes. (In Russian). Retrieved April 23, 2015, from http://www.forbes.ru/tekhnologii/ tekhnika-i-biznes/285793-petlyavremeni-kak-biznes-izobretaet-transport-budushchego

3. Bhandari, M. P. (2019). Sustainable Development: Is This Paradigm The Remedy of All Challenges? Does Its Goals Capture the Essence of Real Development and Sustainability? With Reference to Discourses, Creativeness, Boundaries and Institutional Architecture. SocioEconomic Challenges, 3(4), 97-128. http:// doi.org/10.21272/sec.3(4).97128.2019 .

4. Chatti, W. (2020). Information and communication technologies, road freight transport, and environmental sustainability. Environmental Economics, 11(1), 124-132. https://dx.doi.org/10.21511/ ee.11(1).2020.11

5. Darguzhit, J. (2011). "Belaya kniga" transportnoi politiki ES - vyzov dlya perevozchikov? [Is "White Paper" of the EU transport policy a challenge for carriers?]. Cargonews.
(In Russian). Retrieved May 5, 2011, from http://www.cargonews. ua/aktualii/belaya-kniga-transportnoy-politiki-es-vyzov-dlyaperevozchikov/

6. Deloitte \& Touche. (1992). Business strategy for sustainable development. Winnipeg: International Institute for Sustainable Development. Retrieved from https://www. iisd.org/system/files/publications/ business_strategy.pdf

7. Dimić, S., Pamučar, D., Ljubojević, S., \& Đorović, B. (2016). Strategic Transport Management Models The Case Study of an Oil Industry. Sustainability, 8(9), 954. https:// doi.org/10.3390/su8090954

8. Domergue, P., \& Markovic-Chénais, S. (2012). Greening Transport: Reduce External Costs. Paris: International Union of Railways. Retrieved from https://uic.org/ IMG/pdf/external-costs2012brochure_complete_web-2.pdf

9. Durana, P., Michalkova, L., Privara, A., Marousek, J., \& Tumpach, M. (2021). Does the life cycle affect earnings management and bankruptcy? Oeconomia Copernicana, 12(2), 425-461. https://doi. org/10.24136/oc.2021.015

10. European Commission (EC). (2020). Sustainable and Smart Mobility Strategy. Retrieved September 2, 2021, from https://ec.europa. eu/info/law/better-regulation/ have-your-say/initiatives/12438Sustainable-and-Smart-MobilityStrategy_en

11. Garkushina, S. V. (2008). Otsenka effektivnosti ispolzovaniya alternativnykh vidov motornogo topliva na transporte regiona [Evaluation of the effectiveness of alternative types of motor fuel in transport in the region]. Bulletin of VolSU, 3(1(12)), 138-141. (In Russian). Retrieved from https:// cyberleninka.ru/article/n/otsenkaeffektivnosti-ispolzovaniyaalternativnyh-vidov-motornogotopliva-na-transporte-v-regione/ viewer

12. Golubtsova, Yu. O. (2020). Metody strategicheskogo planirovaniya deyatelnosti sovremennogo predpriyatiya [Methods of strategic planning of a modern enterprise]. Aktualnye Issledovaniya - Actual Research, 17(20), 68-71. (In Russian). Retrieved from https://apni. ru/article/1179-metodi-strategicheskogo-planirovaniya-deyatel

13. Green Economy Financing Facility (GEFF). (2021). Supporting sustainable public transport in Slovakia. Retrieved from https:// ebrdgeff.com/projects/supportingsustainable-public-transport-inslovakia/

14. Horobchenko, D., \& Voronenko, V. (2018). Approaches to the formation of a theoretical model for the analysis of environmental and economic development. Journal of Environmental Management and Tourism, 9(5), 1108-1119. https://doi.org/10.14505//jemt. v9.5(29).24

15. Interfax. (2015). "Transport budushchego" vot-vot predlozhit miru Belarus: peremeshchenie nad zemlei na sumasshedshikh skorostyakh po relsam i strunam [Belarus is about to offer "transport of the future" to the world: moving 
above the ground at crazy speeds along rails and wires]. (In Russian). Retrieved October 23, 2015, from https://www.interfax.by/news/belarus/1192142

16. Kartanaite, I., Kovalov, B., Kubatko, O., \& Krušinskas, R. (2021). Financial modeling trends for production companies in the context of Industry 4.0. Investment Management and Financial Innovations, 18(1), 270-284. http://dx.doi. org/10.21511/imfi.18(1).2021.23

17. Klymchuk, O., Khodakivska, O., Kovalov, B., Brusina A., Benetyte, R., \& Momotenko, I. (2020). World trends in bioethanol and biodiesel production in the context of sustainable energy development. International Journal of Global Environmental Issues, 19(1/2/3), 90-108. https:// dx.doi.org/10.1504/IJGENVI.2020.114867

18. Koilo, V. (2019). Sustainability issues in maritime transport and main challenges of the shipping industry. Environmental Economics, 10(1), 48-65. https://dx.doi. org/10.21511/ee.10(1).2019.04

19. Kraus, S., \& Kauranen, I. (2009). Strategic management and entrepreneurship: Friends or foes? International Journal of Business Science \& Applied Management, 4(1), 37-50. Retrieved from https:// www.business-and-management. org/download.php?file=2009/4_1-37-50-Kraus,Kauranen.pdf

20. Kurbatova, T., Sotnyk, I., Kubatko, O., Arakpogun, E. O., \& Roubik, H. (2020). State support policy for renewable energy development in emerging economies: The case of Ukraine. International Journal of Global Environmental Issues, 19(1/2/3), 26-52. https:// dx.doi.org/10.1504/IJGENVI.2020.114864

21. Matsenko, O., \& Ovcharenko, D. (2013). The quality of energy resources controlling as a part of effective enterprise management. Economic Annals-XXI, 9-10(1), 75-78.

22. Ministry of Infrastructure of Ukraine (MIU). (2018). National Transport Strategy of Ukraine 2030. Retrieved from https://mtu.gov.ua/
files/for_investors/230118/National\%20Transport $\% 20$ Strategy $\% 20$ of\%20Ukraine.pdf

23. Nadanyiova, M. (2018). Green Marketing and its Use in a Transport Company. LOGI - Scientific Journal on Transport and Logistics, 9(1), 58-69. http://doi.org/10.2478/ logi-2018-0008

24. National Institute for Strategic Studies (NISS). (2013). Mekhanizmy formuvannia rehionalnykh priorytetiv rozvytku [Mechanisms of formation of regional development priorities]. Kyiv: National Institute of Strategic Studies. (In Ukrainian). Retrieved from https://niss.gov.ua/doslidzhennya/ regionalniy-rozvitok/mekhanizmi-formuvannya-regionalnikhprioritetiv-rozvitku

25. Peresadko, G. O., Kovalenko, E. V., \& Kulyk, L. A. (2014). Mechanisms of investing into innovative projects of enterprises. Actual Problems of Economics, 10, 184187. Retrieved from http://nbuv. gov.ua/UJRN/ape_2014_10_24

26. Public Institution "Institute of Environmental Economics and Sustainable Development of the National Academy of Sciences of Ukraine" (PI IEESD of NAS of Ukraine). (2021). Main Page. Retrieved from http://ecos.kiev. ua/eng/

27. Sotnyk, I. M. (2012). Trends and problems in management of production and consumption dematerialization. Actual Problems of Economics, 134(8), 62-67. Retrieved from https://www.researchgate. net/publication/290540180_ Trends_and_problems_in_management_of_production_and_ consumption_dematerialization

28. Sotnyk, I., Hulak, D., Yakushev, O., Yakusheva O., Prokopenko, O. V., \& Yevdokymov, A. (2020a). Development of the US electric car market: Macroeconomic determinants and forecasts. Polityka Energetyczna - Energy Policy Journal, 23(3), 147-164. https://doi. org/10.33223/epj/127921

29. Sotnyk, I., Kurbatova, T., Dashkin, V., \& Kovalenko, Y. (2020b). Green energy projects in households and its financial support in
Ukraine. International Journal of Sustainable Energy, 39(3), 218-239. https://doi.org/10.1080/14786451. 2019.1671389

30. State Statistics Service of Ukraine (SSS of Ukraine). (n.d.). Energy balance of Ukraine. Archives. Retrieved from http://www.ukrstat. gov.ua/operativ/operativ2012/energ/en_bal/arh_2012_e.htm

31. Teles, M. F., \& De Sousa, J. F. (2014). Environmental Management and Business Strategy: Structuring the Decision-Making Support in a Public Transport Company. Transportation Research Procedia, 3, 155-164. https://doi. org/10.1016/j.trpro.2014.10.101

32. Van Grinsven, A. H., Otten, M., Van Den Toorn, E., Van Der Veen, R., Király, J., \& Van Den Berg, R. (2021). Alternative fuel infrastructures for heavyduty vehicles. Research for TRAN Committee. Brussels: European Parliament, Policy Department for Structural and Cohesion Policies. Retrieved from https:// www.europarl.europa.eu/RegData/ etudes/STUD/2021/690901/IPOL_ STU(2021)690901_EN.pdf

33. Voronenko, V., Kovalov, B. Horobchenko, D., \& Hrycenko, P. (2017). The effects of the management of natural energy resources in the European Union. Journal of Environmental Management and Tourism, 8(7), 1410-1419. Retrieved from https://journals. aserspublishing.eu/jemt/article/ view/1777

34. Zhuravka, F., Shkarupa, O., Aiyedogbon, J. O., Adeyinka, O.-B., \& Shkarupa, I. (2020) Factors of macroeconomic growth in $\mathrm{Ni}$ geria: Wages demand, taxes, and entrepreneurship development. Investment Management and Financial Innovations, 17(1), 242252. http://dx.doi.org/10.21511/ imfi.17(1).2020.21 